\title{
Efek Subtitusi Jerami Jagung dengan Pelepah Sawit Fermentasi terhadap Kualitas Susu Sapi Perah
}

\author{
Effects of Corn Forage Substitution with Fermented Palm Frond on Milk Quality \\ of Dairy Cow
}

\author{
Mardalena, S. Syarif dan H. Ediyanto \\ Fakultas Peternakan Universitas Jambi, Kampus Pinang Masak, \\ Jl. Raya Jambi - Ma. Bulian Km 15. Ma. Jambi 36136 Jambi \\ Corresponding e-mail: lenadjamas@yahoo.co.id
}

\begin{abstract}
The current study aimes to determine the percentage of fermentation of palm fronds with prolinas (FPFP) as substitution of corn forage in dairy cattle rations and how affect to milk quality of dairy cows. Experiments used a Latin square design with 4 treatments and 4 periods as replications. The treatment consisted of P0: Forage 55\% + Concentrate 45\% (control), P1: Forage 55\% (90\% corn forage + FPFP 10\%) + 45\% Concentrate, P2: Forage 55\% (80\% corn forage + FPFP 20\% ) + 45\% Concentrate, P3: Forage 55\% (60\% corn forage + FPFP $40 \%)+45 \%$ Concentrate. The parameters measured were dry matter, protein, fat and non fat of dry matter of milk of PFH cows. Data were analyzed using SAS program; further analysis using Duncan's Multiple Range Test. The results showed that corn forage substitution treatment with fermentation of oil palm fronds with prolinas no affect $(\mathrm{P}>0.05)$ to milk protein but can increase $(\mathrm{P}<0.05)$ milk fat. The treatment was decreased $(\mathrm{P}$ $<0.05)$ dry matter milk and non fat of dry matter. The conclusions of this research that the substitution of fermentation of oil palm fronds with prolinas can increased milk fat of dairy cows.
\end{abstract}

Key words: oil palm fronds, prolinas, milk quality.

\begin{abstract}
ABSTRAK
Penelitian bertujuan untuk mengetahui kemampuan pelepah sawit fermentasi dengan prolinas (PSFP) sebagai pengganti jerami jagung dalam ransum sapi perah dan melihat pengaruhnya terhadap kualitas susu sapi perah PFH. Penelitian ini menggunakan sapi perah PFH laktasi ke 4 sebanyak 4 ekor. Penelitian ini menggunakan rancangan bujur sangkar latin (BSL) dengan 4 perlakuan dan 4 periode sebagai ulangan. Perlakuan terdiri dari P0: Hijauan 55\% + Konsentrat 45\% (kontrol), P1: Hijauan 55\% ( 90\% jerami jagung + PSFP 10\%) $+45 \%$ Konsentrat, P2: Hijauan 55\% ( 80\% jerami jagung + PSFP 20\%) + 45\% Konsentrat, P3: Hijauan 55\% ( $60 \%$ jerami jagung + PSFP 40\%) + 45\% Konsentrat. Peubah yang diamati adalah kadar bahan kering, protein, lemak dan bahan kering tanpa lemak susu sapi perah PFH. Data dianalisis menggunakan program SAS; analisis lanjut menggunakan Duncan's Multiple Range Test. Hasil penelitian menunjukkan bahwa perlakuan subtitusi jerami jagung dengan pelepah sawit fermentasi dengan prolinas tidak mempengaruhi $(\mathrm{P}>0,05)$ kadar protein susu tetapi nyata menurunkan $(\mathrm{P}<0,05)$ kadar bahan kering dan bahan kering tanpa lemak susu tetapi meningkatkan kadar lemak susu. Dari hasil penelitian ini dapat disimpulkan bahwa subtitusi jerami jagung dengan pelepah sawit yang difermentasi dengan prolinas meningkatkan kadar lemak susu sapi perah.
\end{abstract}

Kata kunci: pelepah sawit, prolinas, kualitas susu.

\section{PENDAHULUAN}

Pakan ternak adalah persoalan mendasar yang perlu mendapat perhatian khusus oleh peternak. Mengandalkan rumput sebagai pakan ternak sapi pada kondisi sekarang sudah tidak memungkinkan lagi. Ketersediaan lahan yang semakin berkurang dan juga akibat pengaruh iklim menyebabkan kualitas hijauan yang ada juga tidak stabil. Kualitas pakan yang stabil sangat berperan dalam mempertahankan produktivitas sapi perah. Untuk mengatasi hal tersebut perlu dicari pakan inkonvensional yang tersedia dalam jumlah cukup banyak sepanjang tahun. Salah satu bahan pakan yang potensial untuk itu adalah pelepah sawit 
yang merupakan limbah dari perkebunan kelapa sawit. Hasil penelitian Syarif (2010) menunjukkan bahwa pelepah sawit dapat mengganti rumput lapang sampai taraf 50\% karena dapat meningkatkan kecernaan protein, NDF dan ADF dalam rumen sapi potong. Selanjutnya Darlis dan Syarif (2011) melaporkan bahwa kombinasi rumput dengan pelepah sawit memberikan pertambahan bobot badan, efisiensi ransum yang lebih baik dibandingkan dengan pemberian rumput saja. Penggunaan pelepah sawit tidak bisa sampai taraf $100 \%$ karena limbah sawit sebagaimana limbah lainnya mengandung faktor pembatas karena tingginya kandungan serat kasar (Suryadi et al., 2009). Pengolahan pakan serat sudah banyak dilakukan diantaranya pengolahan secara kimia melalui amoniasi dan pengolahan secara biologis melalui fermentasi. Kedua teknik pengolahan ini terbukti mampu memperbaili kualitas pakan serat (Ningrat and Khasrad, 2010).

Penambahan probiotik dalam ransum mampu merangsang pertumbuhan mikroba dalam rumen dan meningkatkan kecernaan pakan pada ternak ruminansia (GigerReverdin et al., 2004; Haddad et al., 2005, Elseed et al., 2007). Pemanfaatan probiotik lokal seperti $S$. cereviciae dan A. oryzae telah diteliti oleh Amin (2007) dengan menambahkan dalam ransum berbahan utama 50\% rumput gajah dan 50\% konsentrat dapat meningkatkan populasi mikroba rumen sebagai konsekuensinya dapat meningkatkan peforman sapi perah dara.

Mardalena et al. (2016) ${ }^{\mathrm{a}}$ menyatakan bahwa pada limbah nenas fermentasi adanya bakteri asam laktat dengan mencirikan koloni berwarna putih mengkilat, koloninya bulat dan bergerigi. Hasil identifikasi molekuler pada koloni BAL menunjukkan bahwa kulit nenas fermentasi mengandung isolat bakteri asam laktat L. plantarum dan L. pentosus. Setelah melalui beberapa uji diantaranya uji pewarnaan gram positif, uji toleransi $L$. plantarum terhadap garam empedu maka kulit nenas fermentasi berpotensi sebagai produk probiotik yang diberi nama prolinas (probiotik kulit nenas). Selanjutnya
Mardalena et al. (2016) ${ }^{\mathrm{b}}$ mendapatkan bahwa pemakaian prolinas pada level $5-7,5 \%$ mampu meningkatkan kecernaan bahan kering dan VFA total pelepah sawit pada rumen sapi secara in vitro.

\section{MATERI DAN METODE}

Penelitian dilakukan di kandang sapi perah kelompok tani Bina Maju Sejahtera Desa Kota Karang Kec. Kumpeh Ulu Kabupaten Muaro Jambi dan Laboratorium Nutrisi Ternak Fakultas Peternakan Universitas Jambi pada tahun 2016.

\section{Ternak dan Pakan Ternak}

Sapi yang digunakan dalam penelitian ini adalah sapi laktasi ke 4 sebanyak 4 ekor. Hijauan yang diberikan terdiri dari jerami jagung, pelepah sawit fermentasi dengan prolinas dan konsentrat yang terdiri dari dedak, ampas tahu dan mineral mix dengan kandungan gizi tertera pada Tabel 1. Pemberian pakan dihitung berdasarkan kebutuhan yaitu 55\% hijauan dan $45 \%$ konsentrat. Pelepah sawit dipotong dengan mesin chopper, kemudian dikeringkan dengan sinar matahari sampai kadar air tinggal sekitar 60\%. Pelepah sawit ditambahkan molases $2,5 \%$ dan prolinas $2,5 \%$, dicampur secara merata kemudian disimpan dalam suasana an aerob selama 3 minggu.

Penelitian menggunakan rancangan Bujur Sangkar Latin dengan 4 perlakuan dengan 4 periode sebagai ulangan. Perlakuan yang diberikan adalah subtitusi jerami jagung dengan pelepah sawit fermentasi dengan prolinas yang terdiri dari :

P0: Hijauan $55 \%+$ Konsentrat $45 \%$ (kontrol),

P1: Hijauan 55\% (jerami jagung 90\% + PSFP $10 \%$ ) $+45 \%$ Konsentrat.

P2: Hijauan 55\% (jerami jagung $80 \%+$ PSFP 20\%) $+45 \%$ Konsentrat.

P3: Hijauan 55\% (jerami jagung 60\% + PSFP $40 \%$ ) $+45 \%$ Konsentrat.

Peubah yang diamati adalah :

1. Kadar bahan kering susu didapat dengan cara pengerinagn sampel susu 
Tabel 1. Kandungan mutrisi pakan hijauan, konsentrat dan pelepah sawit fermentasi

\begin{tabular}{lccc}
\hline \multirow{2}{*}{ Nutrisi Pakan (\%) } & Jerami Jagung & Bahan Pakan Perlakuan & Konsentrat \\
\hline Bahan kering & 77,86 & 83,57 & 87,23 \\
Protein & 6,57 & 6,58 & 10,09 \\
Lemak kasar & 1,17 & 2,18 & 1,41 \\
Serat kasar & 21,43 & 32,70 & 26,42 \\
Kadar Abu & 5,15 & 6,99 & 10,21 \\
\hline
\end{tabular}

*) Pelepah sawit fermentasi

Tabel 2. Komposisi bahan pakan dan nutrisi dalam ransum perlakuan.

\begin{tabular}{lcccc}
\hline \multicolumn{1}{c}{ Pakan } & \multicolumn{5}{c}{ Perlakuan } \\
\hline Pelepah Sawit & P0 & P1 & P2 & P3 \\
Hijauan & 0 & 5,5 & 11 & 22 \\
Konsentrat & 55 & 49,5 & 44 & 33 \\
\hline Susunan Nutrisi Ransum (\%) & 45 & 45 & 45 & 45 \\
\hline Bahan kering & 79,14 & 79,45 & 79,76 & 80,39 \\
Protein Kasar & 15,63 & 15,72 & 15,81 & 16,00 \\
Lemak kasar & 2,05 & 2,11 & 2,16 & 2,27 \\
Serat kasar & 25,95 & 26,57 & 27,19 & 28,43 \\
\hline
\end{tabular}

di dalam oven dengan suhu $100-102$ ${ }^{\circ} \mathrm{C}$.

2. Kadar protein susu diukur dengan menggunakan metode Kjedal

3. Kadar lemak dan bahan kering tanpa lemak (BKTL) diukur dengan metode Gerber

Data diolah dengan program SAS (2007). Uji lanjut's Multiple Range Test (DMRT) digunakan jika terjadi perbedaan antar perlakuan.

\section{HASIL DAN PEMBAHASAN}

\section{Kadar Bahan Kering Susu dan Bahan Kering Tanpa Lemak Susu}

Perlakuan subtitusi jerami jagung dengan pelepah sawit fermentasi nyata menurunkan $(\mathrm{P}<0,05)$ kadar bahan kering dan kadar bahan kering tanpa lemak susu sapi perah PFH.

Pada Tabel 3 terlihat bahwa kadar bahan kering dan kadar bahan kering tanpa lemak susu sapi perah pada penelitian ini masih dalam kisaran normal yaitu kadar bahan kering susu 1,19\% - 13,58\% dan kadar bahan kering tanpa lemak susu 5,87\% 9,78\% . Menurut Mukhtar (2006) kandungan nutrien susu sapi terdiri atas bahan kering $12,75 \%$, lemak $3,8 \%$, protein $3,5 \%$ dan laktosa $4,8 \%$.

Tabel 3. Kadar bahan kering dan bahan kering tanpa lemak susu sapi perah PFH menurut perlakuan

\begin{tabular}{lcccc}
\hline \multirow{2}{*}{ Peubah } & \multicolumn{4}{c}{ Perlakuan } \\
\cline { 2 - 5 } & P0 & P1 & P2 & P3 \\
\hline Kadar BK (\%) & $13,58^{\mathrm{a}}$ & $12,23^{\mathrm{b}}$ & $11,75^{\mathrm{bc}}$ & $11,19^{\mathrm{c}}$ \\
Kadar BKTL (\%) & $9,78^{\mathrm{a}}$ & $8,23^{\mathrm{a}}$ & $7,95^{\mathrm{a}}$ & $5,87^{\mathrm{b}}$ \\
\hline
\end{tabular}

P0 $=$ Hiajaun + konsentrat (kontrol), P1 $=($ Hijauan 90\% + PSFP 10\%) + Konsentrat, $\mathrm{P} 2=($ Hijauan $80 \%+$ PSFP $20 \%)+$ Konsentrat, P3 $=($ Hijauan $60 \%+$ PSFP $40 \%) \quad+$ Konsentrat. PSFP $=$ Pelepah sawit fermentasi dengan prolinas. Nilai superskrip yang berbeda pada baris yang sama, menunjukkan perbedaan nyata pada taraf $5 \%$. 
Menurut standar minimal SNI (2011) bahwa susu sapi harus mengandung minimum bahan kering $10,8 \%$, lemak $3 \%$, bahan kering tanpa lemak $7,8 \%$, protein $2,8 \%$ dan laktosa $4,6 \%$.

Hasil uji lanjut DMRT menunjukkan bahwa kadar bahan kering susu antara perlakuan P0, P1, P2 dan P3 menunjukkan perbedaan yang nyata $(\mathrm{P}<0,05)$. Subtitusi jerami jagung dengan pelepah sawit pada perlakuan $\mathrm{P} 0$ nyata $(\mathrm{P}<0.05)$ lebih tinggi dibanding perlakuan P1, P2 dan P3 terhadap bahan kering susu sapi perah (Tabel 3.). Kadar bahan kering susu tertinggi diperoleh pada sapi perah yang diberi ransum P0 $(13,58 \%)$ dan terendah pada sapi yang mendapat perlakuan P3 (11,19\%). Kadar bahan kering susu sangat dipengaruhi oleh asupan nutrien asal ransum dan protein mikroba (Coller, 1985). Lebih tingginya kadar bahan kering susu pada P0 disebabkan konsumsi ransum dan produksi susu juga lebih tinggi dibanding perlakuan yang lainnya. Tingginya konsumsi ransum pada P0 disebabkan karena palatabilitas sapi untuk pakan jerami jagung lebih tinggi dibanding pakan pelepah sawit fermentasi prolinas. Prolinas sebagai akselerator fermentasi yang mengandung bakteri $L$. plantarum belum mampu merangsang peningkatan konsumsi pakan sapi perah sehingga kadar bahan kering susu yang dihasilkan juga tidak meningkat.

Kadar bahan kering tanpa lemak susu pada perlakuan P0, P1, P2 dan P3 menunjukkan perbedaan yang nyata $(\mathrm{P}<0,05)$. Subtitusi hijauan dengan pelepah sawit pada perlakuan $\mathrm{P} 0$ nyata $(\mathrm{P}<0.05)$ lebih tinggi dibanding perlakuan $\mathrm{P} 1, \mathrm{P} 2$ dan P3 terhadap kadar bahan kering tanpa lemak susu sapi perah (Tabel 3). Kadar bahan kering tanpa lemak susu tertinggi diperoleh pada sapi perah yang diberi ransum P0 $\left(9,78^{\mathrm{a}}\right.$ \%) dan terendah pada sapi yang mendapat perlakuan P3 (5,87\%).

\section{Kadar Protein dan Lemak Susu}

Perlakuan subtitusi jerami jagung dengan pelepah sawit fermentasi nyata tidak mempengaruhi $(\mathrm{P}>0,05)$ kadar protein susu tetapi nyata $(\mathrm{P}<0,05)$ meningkatkan kadar lemak susu sapi perah PFH. Kadar protein pada penelitian ini adalah 5,40\% - 5,78\%. Kadar protein susu pada penelitian ini diatas standar minimal Milk Codex yaitu 2,8\%. Menurut Foley et al. (1973) protein susu berasal dari dua sumber yaitu protein sintesis de novo kelenjar ambing dan protein yang lansung ditransfer dari darah. Sekitar 90 95\% protein susu ( $\alpha$ kasein, $\beta$ kasein, $\gamma$ kasein, $\alpha$ laktalbumin dan $\beta$ laktoglobulin) disintesis di ambing dari asam amino esensial dan non esensial yang berasal dari dalam darah. Sisanya $5-10 \%$ protein susu lainnya (immonoglobulin, serum albumin dan $\gamma$ kasein) langsung ditransfer dari darah tanpa mengalami perubahan. Kadar protein susu relatif tetap sepanjang laktasi.

Kadar lemak susu dipengaruhi oleh kandungan serat kasar dan lemak kasar ransum. Ransum yang mengandung serat kasar tinggi atau kecernaan serat kasar yang tinggi akan menghasilkan kadar lemak susu tinggi (Tanuwiria et al., 2009).

Kadar lemak susu pada perlakuan P0, P1, P2 dan P3 menunjukkan perbedaan yang nyata $(\mathrm{P}<0,05)$. Subtitusi hijauan dengan pelepah sawit pada perlakuan P3 nyata $(\mathrm{P}<0.05)$ lebih tinggi dibanding perlakuan P1, P2 dan P0 terhadap kadar lemak susu sapi perah (Tabel 4).

Tabel 4. Kadar protein dan lemak susu sapi perah PFH menurut perlakuan

\begin{tabular}{lcccc}
\hline \multirow{2}{*}{ Peubah } & \multicolumn{4}{c}{ Perlakuan } \\
\cline { 2 - 5 } & P0 & P1 & P2 & P3 \\
\hline Kadar protein (\%) & 5,78 & 5,61 & 5,44 & 5,40 \\
Kadar lemak (\%) & $3,80^{\mathrm{b}}$ & $4,00^{\mathrm{b}}$ & $4,03^{\mathrm{b}}$ & $5,325^{\mathrm{a}}$ \\
\hline
\end{tabular}

$\mathrm{P} 0=$ Hiajaun + konsentrat $($ kontrol), $\mathrm{P} 1=($ Hijauan $90 \%+$ PSFP $10 \%)+$ Konsentrat, $\mathrm{P} 2=($ Hijauan $80 \%+$ PSFP 20\%) + Konsentrat, P3 $=($ Hijauan $60 \%+$ PSFP 40\% $)+$ Konsentrat. PSFP $=$ Pelepah sawit fermentasi dengan prolinas. Nilai superskrip yang berbeda pada baris yang sama, menunjukkan perbedaan nyata pada taraf $5 \%$. 
Kadar lemak susu tertinggi diperoleh pada sapi perah yang diberi ransum P3 $(5,325 \%)$ dan terendah pada sapi yang mendapat perlakuan P0 $(3,8 \%)$. Hal ini disebabkan kandungan serta kasar pada perlakuan P3 lebih tinggi dibanding perlakuan P1, P2 dan P0 (Tabel 4). Menurut Puastuti (2009) mikroba rumen memungkinkan ternak memperoleh energi dari serat kasar. Ditambahkan oleh Sudono dan Sutardi (2003) bahwa pakan hijauan menyebabkan kadar lemak susu tinggi karena lemak susu tergantung dari kandungan serat kasar dalam pakan. Selanjutnya Andriawan et al. (2014) menyatakan bahwa komponen utama dalam pembentukan lemak susu yang diserap oleh kelenjar susu dalam jumlah cukup banyak untuk sintesis lemak susu adalah berasal dari glukosa, asetat, beta hidroksibutirat dan trigliserida dalam darah. Didukung dari hasil penelitian pelepah sawit fermentasi dengan prolinas oleh Mardalena et al. $(2016)^{\mathrm{b}}$ bahwa pelepah sawit fermentasi dengan prolinas menghasilkan kandungan asam asetat lebih tinggi dibanding asam propionat di dalam rumen secara in vitro.

\section{KESIMPULAN DAN SARAN}

Dari hasil penelitian ini dapat disimpulkan bahwa subtitusi hijauan dengan pelepah sawit yang difermentasi dengan prolinas (probiotik kulit nenas) meningkatkan kadar lemak susu.

\section{UCAPAN TERIMA KASIH}

Penulis mengucapkan terima kasih kepada Direktur Riset dan Pengabdian Kepada Masyarakat, Kementerian Riset, Teknologi, dan Pendidikan Tinggi Republik Indonesia, yang telah menyediakan dana program penelitian Hibah Bersaing Tahun kedua sesuai dengan Surat Perjanjian Kontrak Penelitian Nomor: 1/UN21.6LT/2016 Tanggal 28 Maret 2016.

\section{DAFTAR PUSTAKA}

Amin, M. 2007. Pengaruh penggunaan probiotik Sacharomyces cereciviae dan Aspergillus niger dalam ransum pada populasi mikroba, aktivitas fermentasi rumen, kecernaan dan pertumbuhan sapi perah dara. Program Pascasarjana. IPB, Bogor.

Andriawan, T., D. W. Harjanti dan P. Sambodho. 2014. Hubungan antara konsumsi serat kasar terhadap produksi dan lemak susu sapi perah di peternakan rakyat Kabupaten Klaten. Anim. Agr. J. 3(3): 383 - 388.

Badan Standardisasi Nasional, Standar Nasional Indonesia 3141.1. 2011. Susu Segar, Bagian 1: Sapi.

Darlis dan S. Suhessy. 2011. Pengaruh Penggunaan Pelepah Sawit terhadap Pertumbuhan Sapi Bali. Prosiding Seminar Nasional Vol.3. Fakultas Pertanian Universitas Sriwijaya.

Dickinson, F. N. and H.A. Tucker. 1973. Dairy Cattle, Principles, Practices, Problems, Profits. Lea and Febiger, Philadelphia.

Elseed, F., A.M.A, Rania, M.A. Abusamra. 2007. Effects of Supplemental Yeast (Saccharomyces cerevisiae) Culture on NDF Digestibility and Rumen Fermentation of Forage Sorghum Hay in Nubian Goat's Kids. Res. J. Agric. \& Biol. Sci. 3(3): 133-137.

Giger-Reverdin, S., D. Sauvant, J. Tessier, G.Bertin, P. and Morand-Fehr, 2004. Effect of live yeast culture supplementation on rumen fermentation in lactating dairy goats. S. Afri. J. Anim. Sci., 34: 89-91.

Haddad, S.G., S.N. Goussous, 2005. Effect of yeast culture supplementation on nutrient intake, digestibility and growth performance of Awassi lambs. 
Anim. Feed Sci. Technol. 118: 343348.

Mardalena, S. Syarif and S. Erina 2016 Molecular characteristics and identification of lactic acid bacteria of pineapple waste as probiotics candidates for ruminants. Pakistan Journal of Nutrition. 15 (6): $519-$ 523.

Mardalena, S. Syarif dan Akmal. 2016 ${ }^{\mathrm{b}}$. Efek pemberian pelepah sawit yang difermentasi dengan prolinas terhadap karakteristik rumen sapi perah PFH. Jurnal Ilmu-ilmu Peternakan. 19 (2): 55 - 62.

Mukhtar, A. 2006. Ilmu Produksi Ternak Perah. Surakarta LPP UNS dan UNS Press. Surakarta.

Ningrat, R.W.S. and Khasrad, 2010. Improving carcass quality of indigenous cattle of West Sumatera fed local feed resources. Pakistan Journal of Nutrition. 9 (8): 822-826.

Puastuti, W. 2009. Manipulasi bioproses dalam rumen untuk meningkatkan penggunaan pakan berserat. Wartazoa. 19 (4): 180 - 190.

Thomas, P.C. and P. A. Martin, 1988. The influence of nutrient balance on milk yield and competition in gransworthy. P.C. Nutrition and Lactation in The Dairy Cow Butterworths. London, Boston, Singapore, Sydney, Toronto, Wellington.

Syarif., S. 2010. Kecernaan In Vitro Ransum yang Mengandung Pelepah Sawit (Digestibility Value of Diet Wich Included Palm of Frond/POF). Jurnal Embrio 2 (3) : $41-48$.

SAS. 2007. SAS/STAT User's Guide (Release 9.1.3 Ed.). SAS Institute Incorporation Cary. North Carolina.

Sudono, A dan T. Sutardi. 2003. Pedoman Beternak Sapi Perah.Direktorat Jendral Peternakan, Jakarta.

Suryadi, M. Afdal dan A. Latief. 2009. Pengaruh Penggantian Rumput dengan Pelepah Sawit Ditinjau dari Segi Kecernaan dan Fermentabilitas Secara In Vitro Gas. Jurnal Ilmiah Ilmu-Ilmu Peternakan.12 (1) : 29 34.

Tanuwiria, U.H., A. Rohana, Mansyur dan L. Budimulyati. 2009. Perbaikan efisiensi ransum yang diberi hasil samping wortel, sebagai pengganti rumput lapang. Buletin Ilmu Peternakan dan Perikanan. 13 (2) : 82-92 